\title{
LACTIC ACID PRODUCTION BY Lactobacillus sp. FROM BIODIESEL DERIVED RAW GLYCEROL
}

\author{
PRODUCCIÓN DE ÁCIDO LÁCTICO POR Lactobacillus sp. \\ A PARTIR DE GLICEROL CRUDO DEL BIODIESEL
}

\begin{abstract}
Yessica Prada-Palomoํㅡ, Marly Romero-Vanegas¹, Pedro Díaz-Ruíz ${ }^{1}$ Daniel Molina-Velasco ${ }^{1}$ and Carolina Guzmán-Luna ${ }^{1 *}$
\end{abstract}

1 Universidad Industrial de Santander, Bucaramanga, Santander, Colombia

e-mail:cgluna74@gmail.com

(Received Jul. 10, 2012; Accepted Nov. 01, 2012)

\section{ABSTRACT}

$\mathrm{L}$ actic Acid (LA) is a versatile compound with extensive industrial usage. Lactic Acid Bacteria (LAB) are renowned for their capacity to ferment carbohydrates to LA. In the biodiesel industry, bioconversion of residual glycerol to monomers of biopolymers, such as $L A$, is an alternative for usage of this waste as raw material to produce a high value added biotechnological compound. This research evaluates LA production through fermentation processes using a Lactobacillus sp. native strain and raw glycerol from the biodiesel industry. Native strain was isolated from the processing of dairy, fruit, and vegetable products and through cultures in Man, Rogosa \& Sharpe agar (MRS). After an adaptation phase, the fermentative capability of the strain was evaluated through chemical quantification of metabolites using Nuclear Magnetic Resonance

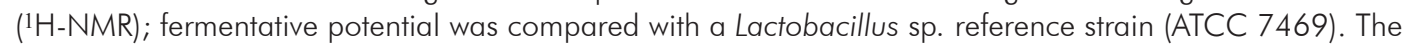
native strain Lactobacillus sp. CYP4 showed a higher bioconversion potential (LA concentration: $39.41 \mathrm{mM}$, conversion percentage: $39.27 \%$, at $24 \mathrm{~h}$, volumetric productivity: $1.28 \mathrm{~g} \cdot \mathrm{L}^{-1} \cdot \mathrm{h}^{-1}$, yield: $0.71 \mathrm{~g} \cdot \mathrm{g}^{-1}$ ) from raw glycerol, when compared to the reference strain.

Keywords: Lactic acid, Biodiesel, Raw glycerol, Native microorganisms, Bioconversion, Fermentation, Nuclear magnetic resonance.

How to cite: Prada-Palomo, Y., Romero-Vanegas, M., Díaz-Ruíz, P., Molina-Velasco, D. \& Guzmán-Luna, C. (2012). Lactic acid production by Lactobacillus sp. from biodiesel derived raw glycerol . CT\&F-Ciencia, Tecnología y Futuro, 5(1), 57-66.

*To whom correspondence should be addressed

+ V Congreso Internacional de Ciencia y Tecnología de los Biocombustibles, CIBSCOL 2012, Universidad Industrial de Santander, Bucaramanga, Santander, Colombia. 5 - 8 de junio de 2012. 


\section{RESUMEN}

E I Ácido Láctico (AL) es un compuesto versátil utilizado ampliamente en la industria. Las Bacterias Ácido Lácticas (BAL) se han reconocido por su capacidad de fermentar carbohidratos a AL. En la industria del biodiesel, la bioconversión del glicerol residual en monómeros de biopolímeros como AL, es una alternativa de aprovechamiento de un residuo como materia prima para el desarrollado de un producto biotecnológico con alto valor agregado. Este trabajo evaluó la producción de AL mediante procesos fermentativos utilizando una cepa nativa de Lactobacillus sp. y glicerol crudo de la industria del biodiesel. La cepa nativa fue aislada del procesamiento de productos lácteos, frutas y verduras, y mediante cultivos en agar Man Rogosa \& Sharpe (MRS). Luego de una fase de adaptación, se evaluó la capacidad fermentativa de la cepa mediante la cuantificación química de metabolitos por Resonancia Magnética Nuclear de protones $\left({ }^{1} \mathrm{H}-\mathrm{RMN}\right)$; el potencial fermentativo fue comparado con una cepa de referencia de Lactobacillus sp. (ATCC 7469). La cepa nativa Lactobacillus sp. CYP4 tuvo mayor potencial de bioconversión (concentración de ácido láctico: $39.41 \mathrm{mM}$, porcentaje de conversión: $39.27 \%$, a las $24 \mathrm{~h}$, productividad volumétrica: $1.28 \mathrm{~g} \cdot \mathrm{L}^{-1} \cdot \mathrm{h}^{-1}$; rendimiento: $\left.0.71 \mathrm{~g} \cdot \mathrm{g}^{-1}\right)$, a partir de glicerol crudo, en comparación con la cepa de referencia.

Palabras clave: Ácido láctico, Biodiesel, Glicerol crudo, Microorganismos nativos, Bioconversión, Fermentación, Resonancia magnética nuclear.

\section{RESUMO}

Ácido Láctico ( $\mathrm{AL}$ ) é um composto versátil utilizado amplamente na indústria. As Bactérias Ácido Lácticas (BAL) foram reconhecidas pela sua capacidade de fermentar carboidratos a AL. Na indústria do biodiesel, a bioconversão do glicerol residual em monômeros de biopolímeros como AL, é uma alternativa de aproveitamento de um resíduo como matéria prima para o desenvolvimento de um produto biotecnológico com alto valor agregado. Este trabalho avaliou a produção de AL mediante processos fermentativos utilizando una cepa nativa de Lactobacillus sp. e glicerol cru da indústria do biodiesel. A cepa nativa foi isolada do processamento de produtos lácteos, frutas e verduras e mediante culturas em ágar Man Rogosa \& Sharpe (MRS). Logo de um processo de adaptação se avaliou a sua capacidade fermentativa mediante a quantificação química de metabólitos por Ressonância Magnética Nuclear de protões (1 H-RMN). $O$ potencial fermentativo foi comparado com una cepa de referência de Lactobacillus sp. (ATCC 7469). A cepa nativa Lactobacillus sp. CYP4 teve maior potencial de bioconversão (concentração de ácido láctico: 39.41 $\mathrm{mM}$; porcentagem de conversão: $39.27 \%$, às $24 \mathrm{~h}$, Produtividade volumétrica: $1.28 \mathrm{~g} . \mathrm{L}^{-1} . \mathrm{h}^{-1}$, Rendimento: $0.71 \mathrm{~g}^{-1} \mathrm{~g}^{-1}$, a partir de glicerol cru, em comparação com a cepa de referência.

Palavras chave: Ácido láctico, Biodiesel, Glicerol cru, Micro-organismos nativos, Bioconversão, Fermentação, Ressonância magnética nuclear. 


\section{INTRODUCTION}

The global energy crisis has promoted the industrialization of biodiesel, with the European Union (EU) leading this effort worldwide, presenting an increase in total production from 3.2 million metric tons (MMT) in 2005 to 5.71 MMT in 2007 and 9.57 MMT in 2010. In spite of the latter moderate increase, during the first half of 2011, it was registered a decrease to 8 MMT. Germany and France are the countries with the highest production (Fischer et al., 2009; European Biodiesel Board, 2011). Moreover, in the U.S. biodiesel production has been increasing dramatically from 25 million gallons in 2004 to 1.1 billion gallons in 2011, equivalent to approximately 3.57 MMT (National Biodiesel Board, 2012). Countries like China, Brazil, Argentina, Indonesia and Malaysia have shown a rapid expansion in their ability to produce biodiesel (Du et al., 2008). Colombia produced 443.037 tons of biodiesel from African palm oil in 2011 and generated approximately 44.304 tons of crude glycerol. By 2020, production is expected to be six times greater than the market demand (Federación Nacional de Biocombustibles en Colombia, 2012). On a global scale, production for 2016 is estimated at 37 billion gallons (120 MMT approximately), and from which 4 billion gallons of glycerol will be produced (Sims, 2007).

Glycerol is the main byproduct of the biodiesel industry and represents between $10-40 \%\left(p \cdot p^{-1}\right)(0.35$ kilograms per gallon of biodiesel) when vegetable oils are used as raw material (da Silva, Mack \& Contiero, 2009). Worldwide, glycerol overproduction has generated a surplus in the market which, in turn, has led the price to drop to minimum values - to the point that it is considered as an industrial residue- and causing the shutdown of its production by chemical synthesis at companies such as Dow Chemical and Procter and Gamble Chemical (da Silva et al., 2009; Yazdani \& González, 2007).

Currently, glycerol is refined by filtration methods, chemical additives, and vacuum fractional distillation in order to remove impurities and produce various commercial grades. However, the difficulty of this process lies in that these treatments increase the production cost. An alternative is to transform this raw material into higher value-added products with low environmental toxicity (Johnson \& Taconi, 2007).
Among the conversion processes are chemical catalysis, which has the disadvantage of low specificity in the products, the use of high pressures and temperatures, and non-use of crude glycerol because of its high levels of pollutants. Regarding the bioconversion processes, microorganisms use crude glycerol as a carbon source to produce organic acids such as lactic acid, succinic acid, and acetic acid; alcohols such as 1.3-propanediol and ethanol; aldehydes such as 3-hydroxypropionaldehyde; polyhydroxyalkanoates; hydrogen, among other compounds, with direct benefits to the environment that promotes the use of biodiesel. (El-Ziney et al., 1998; Claisse \& LonvaudFunel, 2000; Sauvageot, Gouffi, Laplace \& Auffray, 2000; Lüthi-Peng, Dileme \& Puhan, 2002; Garai-Ibabe et al., 2008; da Silva et al., 2009)

LA (2-hydroxypropanoic acid) is a versatile compound used in the chemical, pharmaceutical, food, and plastics industries (Hofvendahl \& Hahn-Hägerdal, 2000; Wee, Kim \& Ryu, 2006; Okano et al., 2010). It is produced from easily fermentable substrates such as glucose, sucrose, and starch, which are derived from corn, potato, cassava and barley, all essentials for human consumption. Therefore, the production of LA from crude glycerol guarantees industrial sustainability in terms of food security.

LA chemical synthesis, besides being expensive, has the disadvantage of producing a mix of optically inactive isomers, and as a result, $90 \%$ of the LA generated in the world is produced via biotechnology. The fermentation process uses bacteria and fungi that assimilate substrates rich in carbohydrates, and has the advantage of forming optically active D (-) or L (+) enantiomorphs, (Hofvendahl \& Hahn-Hägerdal, 2000). Moreover, as a product of industrial value, there is polylactic acid (produced from the D- and L-lactate), which is a renewable polymer, biodegradable, and environmentally friendly.

The LA biotechnological production depends, among other factors, on: the type of microorganism used, the immobilization or recirculation of these microorganisms, $\mathrm{pH}$, temperature, carbon source, nitrogen source, type of fermentation, and formation of byproducts. The bacterial type fermentation is characterized for being fast and metabolizing completely 
the economic substrates, with minimum additions of nitrogen compounds, and growth at lower $\mathrm{pH}$ values, show scant production of biomass, and a negligible amount of byproducts (Hofvendahl \& Hahn-Hägerdal, 2000; Serna-Cock \& Rodríguez-de Stouvenel, 2005).

The LAB's are a group of bacteria named for their ability to ferment carbohydrates to LA. This group is comprised of a range of genera like rods bacteria: Lactobacillus and Carnobacterium, and cocci bacteria: Lactococcus, Leuconostoc, Pediococcus, Streptococcus, among others. Lactobacillus strain includes Gram-positive bacteria, bacilli or coccobacilli, most of them non-spore forming and catalase-negative. Lactobacilli in general are ubiquitous, and are found in almost any environment where carbohydrates are available, such as: food (dairy, fermented meats, sourdough, vegetables, fruits, and beverages), the respiratory tract, the gastrointestinal (GI) tract, human and animal genitals, wastewaters, and vegetal material (Felis, Dellaglio \& Torriani, 2009; König \& Berkelmann-Löhnertz, 2009).

This study evaluate the LA fermentative production from crude glycerol, by a native strain of Lactobacillus, in terms of the consumption of substrate, percentage of efficiency or conversion, and the volumetric productivity. Results were compared with Lactobacillus rhamnosus ATCC7469 strain cited in the literature as being the largest lactic acid producer from USP grade glycerol (Álvarez et al., 2004). The use of LAB for the best utilization of this waste is an attractive biotechnological option for the sustainability of the biodiesel industry.

\section{METHODS}

\section{Lactobacillus Strains Used and Adaptation Conditions}

The native strain of Lactobacillus sp. CYP4 (isolated in a "screening" of fermented milk matrixes, fruits, and vegetables) and the reference strain Lactobacillus rhamnosus ATCC 7469 were cultured in MRS agar at $37^{\circ} \mathrm{C}$ for 48 hours under anaerobic and aerobic conditions, respectively. These culture conditions were identified in previous studies, using as selection criteria the highest crude glycerol assimilation (as carbon source) for each microorganism.
The adaptation of the microorganisms was carried out in MRS broth modified with crude glycerol $(217.17 \mathrm{~mm})$, obtained from a Colombian producer of biodiesel. As control assay, an unmodified MRS broth was used. The glucose (for growth control) and the crude glycerol were sterilized separately and subsequently added.

\section{Fermentation Conditions}

Tests were conducted with microbial cultures in exponential state. Operational volume: $50 \mathrm{~mL}$. The biomass comparison was made with turbidity readings (optical density, OD: $540 \mathrm{~nm}$ ) during 24 hours. The supernatant was obtained through centrifugation (4000 $\mathrm{rpm}, 15 \mathrm{~min}$ ) and filtration with PVDF membranes, with pore diameter of $0.45 \mu \mathrm{m}$ (polyvinylidene difluoride, OlimPeak, Spain). The sample was preserved at $4{ }^{\circ} \mathrm{C}$ for the chemical analysis of metabolites. Each fermentation test was developed in triplicate.

\section{Quantification and Analysis of Metabolites}

During each measurement, $4 \mathrm{~mL}$ of the filtered supernatant were taken. The analysis was performed by Nuclear Magnetic Resonance (NMR), the ${ }^{1} \mathrm{H}$ NMR spectra were obtained with Bruker Avance III $400 \mathrm{MHz}$ spectrometer, the delay time between scans was $4 \mathrm{~s}$ and the spectra were archived with 8 scans. Presaturation of the solvent (water) was made at the frequency of 4.7 ppm in order to substantially reduce its spectral intensity, using the Bruker pulse sequence zgpr. As an internal quantification standard, N, N-dimethylformamide (DMF), was used. Because of its low number of signals and its chemical shift $(\delta, \mathrm{ppm})$, it does not interfere in the integration zone of the signals of interest. The phase and baseline of resulting spectra was manually adjusted and corrected after using a very large expansion of the $y$ axis. The bioconversion efficiency of the crude glycerol was evaluated according to the percentage of yield ( $\left.Y^{\prime} p s\right)$ parameters, the crude glycerol consume percentage $(\% \mathrm{CG})$ and the volumetric productivity $\left(g \cdot L^{-1} \cdot h^{-1}\right)$.

\section{RESULTS}

\section{Adaptation of Lactobacillus Strains}

Triplicate testing showed optimal growth of the strains owing to the preliminary adaptation in the modified MRS 
broth with crude glycerol. The metabolism of the Lactobacillus CYP4 was faster, reaching an optical density of 1.34 at the late exponential phase at $9 \mathrm{~h}$ of growth, compared to 0.91 for Lactobacillus ATCC 7469 during $24 \mathrm{~h}$ of fermentation (Figure 1). Therefore, native strain assimilates better crude glycerol as carbon source.

\section{Quantification and Analysis of Metabolites}

In the quantification of crude glycerol, a group of signals was recorded between 3.33 and $3.38 \mathrm{ppm}(2 \mathrm{H}$, $\mathrm{q},-\mathrm{CH}$ ) marked as (c) area corresponding to the two methyl protons, used for the respective integration (Figure 2).

The crude glycerol sample submitted presented a signal at $3.17 \mathrm{ppm}\left(3 \mathrm{H}, \mathrm{s},-\mathrm{CH}_{3}\right)$ and was assigned to the methyl protons of the acetic acid and marked as (d), which is an impurity of glycerol.

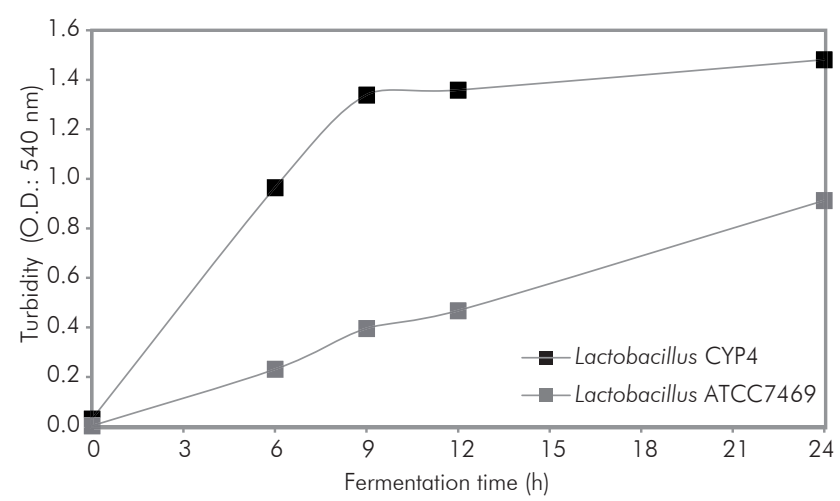

Figure 1. Growth of Lactobacillus CYP4 and L. rhamnosus ATCC7469 in crude glycerol.

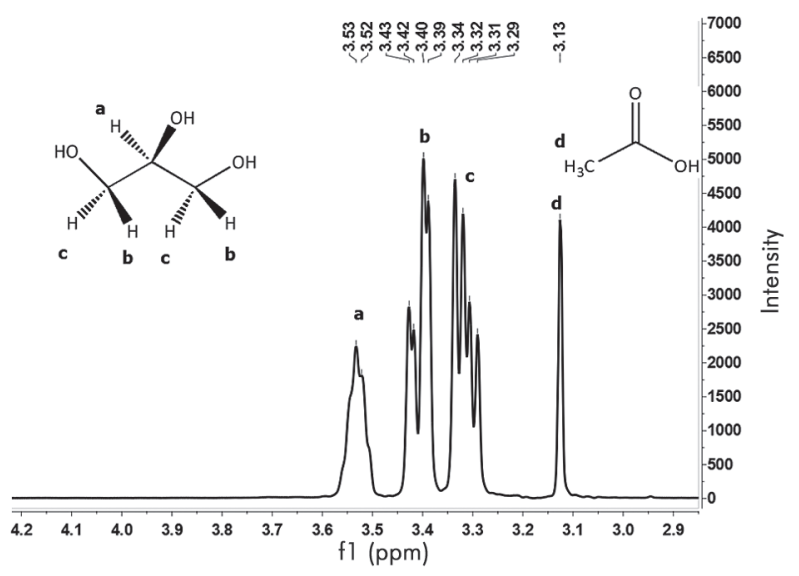

Figure 2. ${ }^{1} \mathrm{H}-\mathrm{RMN}(400 \mathrm{MHz})$ spectra of the crude glycerol used in the fermentations.
Using the signal of the N, N-dimethylformamide (DMF) at $7.84 \mathrm{ppm}$ corresponding to the amide proton, the selected areas of each compound were integrated. The integration of each area and the number of protons that cause it is directly proportional to the molar concentration of the compound. The spectra of DMF, crude glycerol and the metabolites at 24 hours of fermentation of each strain are seen in Figures 3,4 and 5 .

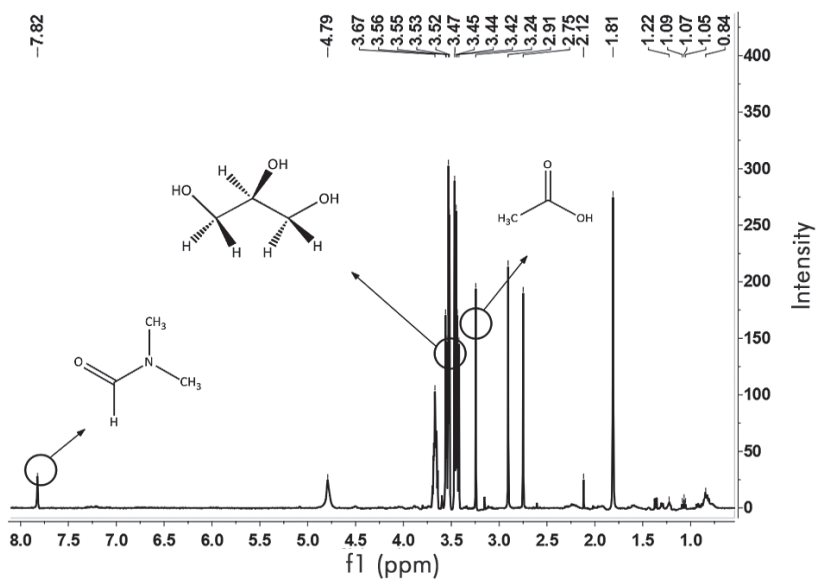

Figure 3. ${ }^{1 \mathrm{H}-\mathrm{RMN}}(400 \mathrm{MHz})$ spectra for the DMF and crude glycerol in the fermentation broth.

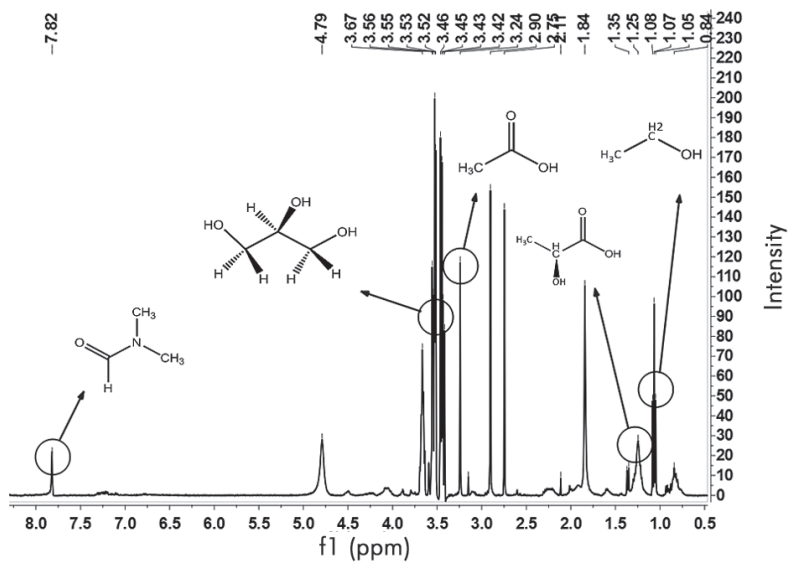

Figure 4. ${ }^{1} \mathrm{H}-\mathrm{RMN}(400 \mathrm{MHz})$ spectra for the metabolites at 24 hours of fermentation of the Lactobacillus CYP4.

Figure 3 shows that the signal of the DMF is a singlet which does not interfere with the other signals. In Figure 4, the characteristic signals of LA at $1.25 \mathrm{ppm}$ and a triplet $\left(3 \mathrm{H}, \mathrm{t},-\mathrm{CH}_{3}\right)$ belonging to the methyl group of the ethanol at $1.08 \mathrm{ppm}$, appear during the 


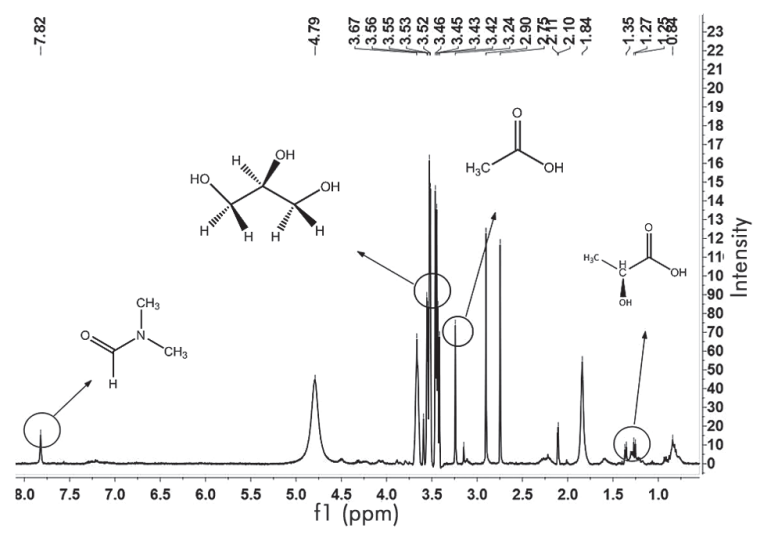

Figure 5. ${ }^{1} \mathrm{H}-\mathrm{RMN}(400 \mathrm{MHz})$ spectra for the metabolites at 24 hours of fermentation of the Lactobacillus rhamnosus ATCC 7469.

fermentation with Lactobacillus CYP4. In Figure 5, the characteristics signals of LA at $1.35 \mathrm{ppm}$ are shown at the fermentation with the reference strain.

The synthesis of glycerol utilization and product formation by Lactobacillus CYP4 and L. rhamnosus ATCC 7469 is shown in Table 1. The differences in fermentation time are related with the specific metabolism of each microorganism and the highest metabolite production achieve during the fermentation process.

The highest consumption of crude glycerol was achieved by the native strain $(82.95 \mathrm{mM})$, indicating a greater assimilation of the carbon source.

In terms of metabolites formation, the native strain Lactobacillus CYP4 achieved, in a continuous form, the highest production of LA at $24 \mathrm{~h}$ of fermentation (46.23 $\mathrm{mM})$. By contrast, the reference strain obtained a LA concentration at $6 \mathrm{~h}(27.65)$ with a maximum value at $12 \mathrm{~h}(27.73 \mathrm{mM})$ and slightly decreased its production at $24 \mathrm{~h}(25.37 \mathrm{mM})$.

Ethanol was another metabolite, useful in the energy industry, obtained during the bioconversion of glycerol by the native strain. The maximum concentration of ethanol attained was $26.94 \mathrm{mM}$ at $24 \mathrm{~h}$ of fermentation and evidence a heterofermentative metabolism by this lactic acid bacteria.

Table 1. Glycerol utilization and product formation by Lactobacillus CYP4 and L. rhamnosus ATCC 7469 during the fermentation process.

\begin{tabular}{|c|c|c|c|c|}
\hline Microorganism & $\begin{array}{c}\text { Glycerol Consumption } \\
(\mathrm{mM})\end{array}$ & $\begin{array}{c}\text { LA Concentration } \\
(\mathrm{mM})\end{array}$ & $\begin{array}{c}\text { Ethanol Concentration } \\
(\mathrm{mM})\end{array}$ & $\begin{array}{c}\text { Fermentation time } \\
(\mathrm{h})\end{array}$ \\
\hline Lactobacillus sp. CYP4 & 82.95 & 46.23 & 26.94 & 24 \\
\hline $\begin{array}{c}\text { L. rhamnosus } \\
\text { ATCC7469 }\end{array}$ & 39.96 & 27.73 & None detected & 12 \\
\hline
\end{tabular}

Note: the values expressed correspond to the average of the triplicate testing.

Table 2. Bioconversion of crude glycerol to LA by Lactobacillus CYP4 and L. rhamnosus ATCC7469.

\begin{tabular}{|c|c|c|c|c|c|c|}
\hline \multirow{2}{*}{$\begin{array}{l}\text { TIME } \\
\text { (h) }\end{array}$} & \multicolumn{3}{|c|}{$\begin{array}{l}\text { Lactobacillus sp. } \\
\text { CYP4 }\end{array}$} & \multicolumn{3}{|c|}{$\begin{array}{l}\text { Lactobacillus rhamnosus } \\
\text { ATCC } 7469\end{array}$} \\
\hline & $\%$ CG & $Y_{p s}^{\prime}(g / g)$ & $Q(g /(L \cdot h))$ & $\% C G$ & $Y_{p s}^{\prime}(g / g)$ & $Q(g /(L \cdot h))$ \\
\hline 6 & 10.14 & 0.52 & 0.71 & 7.27 & 0.80 & 0.83 \\
\hline 9 & 20.93 & 0.71 & 1.28 & 8.37 & 0.48 & 0.38 \\
\hline 12 & 35.80 & 0.44 & 1.02 & 11.50 & 0.51 & 0.42 \\
\hline 24 & 39.27 & 0.51 & 0.66 & 17.36 & 0.27 & 0.17 \\
\hline
\end{tabular}


Table 3. Volumetric productivities of LA utilizing other carbon sources and other microorganisms.

\begin{tabular}{|c|c|c|}
\hline Substrate & Microorganism used & Productivity \\
\hline Wheat & Lactococcus lactis ATCC 19435 & 1.0 \\
\hline Wood & Lactobacillus delbrueckii NRRL 395 & 0.7 \\
\hline Rye & Lactococcus paracasei N8 & 2.4 \\
\hline Rice & Lactococcus sp. RKY2 & 2.9 \\
\hline Sweet sorghum & Lactobacillus paracasei N8 & 2.7 \\
\hline Crude glycerol & Lactobacillus CYP4 & $1.28^{*}$ \\
\hline Crude glycerol & Lactobacillus rhamnosus ATCC 7469 & $0.83^{*}$ \\
\hline
\end{tabular}

This latter compound is currently produced from industrial sugar cane and manioc as a carbon source. In 2011, the Colombian National Federation of Biofuels reported sales of 351.08 million liters of ethanol, a value higher than its production of 336.95 million liters (Federación Nacional de Biocombustibles de Colombia, 2012). Therefore, the fermentation process with Lactobacillus CYP4 derived from crude glycerol can complement this economic course.

To evaluate the efficiency of the fermentation process, the substrate consume percentage, yield percentage, and volumetric productivity were calculated based on the concentration of glycerol and LA measured at different fermentation times (Table 2).

The highest yield value was obtained at $9 \mathrm{~h}$ of fermentation for Lactobacillus CYP4 (0.71 g.g-1) and $6 \mathrm{~h}$ by the reference strain $\left(0.80 \mathrm{~g} \cdot \mathrm{g}^{-1}\right)$. The highest conversion percentage was obtained at $24 \mathrm{~h}$ by the native strain (39.27\%), presenting the highest volumetric productivity at $9 \mathrm{~h}\left(1.28 \mathrm{~g} \cdot \mathrm{L}^{-1} \cdot \mathrm{h}^{-1}\right)$, compared to 0.83 $g \cdot L^{-1} \cdot h^{-1}$ at $6 h$ for the reference strain.

The volumetric productivities obtained by both microorganisms can be compared with the values obtained by Wee et al. (2006) where evaluated different carbon sources (Table 3 ).

The conversion of glycerol to LA and ethanol is an economically viable proposal for the biodiesel industry, and can be integrated into the production plants and establishing true bio-refineries. Not only, it does add value to an industrial waste, but also mitigates environmental pollution. Lactic acid is a primary compound for the production of biopolymers such as polylactic acid with properties similar to polyethylene terephthalate (PET), with greater environmental biodegradability.

\section{CONCLUSIONS}

- The native strain Lactobacillus CYP4 assimilate better the crude glycerol derived from a biodiesel production plant as a carbon source in comparison to the reference strain L. rhamnosus ATCC 7469, cited by its growth in USP glycerol.

- Under the best conditions for each bacterial strain, Lactobacillus CYP4 produced the highest LA (39.41 mM) concentration when compared to $L$. rhamnosus ATCC7469 (10.11 mM). Given the anaerobic fermentation conditions of the native strain, ethanol was produced at a concentration of $26.94 \mathrm{mM}$.

- Lactobacillus CYP4 may be a biotechnological alternative for the use of residual glycerol and its conversion to biopolymer monomers such as LA and alcohols such as ethanol of industrial value.

\section{ACKNOWLEDGEMENTS}

The authors thank: the Vicerrectoria de Investigación y Extension (VIE), DIEF- Research Project stra- 
tegic area No. 5452, the School of Bacteriology and Clinical Laboratory of the Universidad Industrial de Santander (UIS), the Biotechnology and Nuclear Magnetic Resonance facilities UIS, and the Bacteriologist Natalia Andrea Tarazona for her support of this project.

\section{REFERENCES}

Álvarez, M., Medina, R., Pasteris, S., Strasser de Saad, A. \& Sesma, F. (2004). Glycerol metabolism of Lactobacillus rhamnosus ATCC 7469: Cloning and expression of two glycerol kinase genes. J. Mol. Microbiol. Biotechnol., 7(4), 170-181.

Claisse, O. \& Lonvaud-Funel, A. (2000). Assimilation of glycerol by a strain of Lactobacillus collinoides isolated from cider. Food Microbiol., 17(5), 513-519.

Da Silva, G. P., Mack, M. \& Contiero, J. (2009). Glycerol: A promising and abundant carbon source for industrial microbiology. Biotechnol. Advances, 27(1), 30- 39.

Du, W., Li, W., Sun, T., Chen, X. \& Liu, D. (2008). Perspectives for biotechnological production of biodiesel and impacts. Appl. Microbiol. Biotechnol., 79(3), 331-337.

El-Ziney, M. G., Arneborg, N., Uyttendaele, M., Debevere, J. \& Jakobsen, M. (1998). Characterization of growth and metabolite production of $L$. reuteri during glucose/ glycerol cofermentation in batch and continuous cultures. Biotechnol. Lett., 20(10), 913-916.

European Biodiesel Board. (2011). 2010-2011: EU biodiesel industry production forecasts show first decrease in 2011 since data is gathered. [Press release web]. (October $18^{\text {th }}$ 2011). Available at: $<$ http://www.ebb-eu.org/EBBpressreleases/EBB\%20press\%20release \%202010\%20prod\%20 2011_capacity\%20FINAL.pdf>

Federación Nacional de biocombustibles de Colombia. Sector de los Biocombustibles. [Accessed: Nov. 01, 2012]. Available at: $<$ http://www.fedebiocombustibles.com/v2/ main-index.htm>.

Felis, G. E., Dellaglio, F. \& Torriani, S. (2009). Chapter 15: Taxonomy of probiotic microorganisms. In: Charalampopoulos. D. \& Rastall. R. A. Prebiotics and probiotics science and technology. New York: Springer Sience + Business media. 591-637.

Fischer, G., Hizsnyik, E., Prieler, S., Shah, M. \& Van Velthuizen, H. (2009). Biofuels and Food Security. International Institute for applied systems analysis (IIASA). The OPEC Fund for International Development (OFID). Vienna: Stiepan Druck GmbH.

Garai-Ibabe, G., Ibarburu, I., Berregi, I., Claisse, O., Lonvaud-Funnel, A., Irastorza, A. \& Dueñas, M. T. (2008). Glycerol metabolism and bitterness producing lactic acid bacteria in cidermaking. Internat. J. Food Microbiol., 121(3), 253-261.

Hofvendahl, K. \& Hahn-Hägerdal, B. (2000). Factors affecting the fermentative lactic acid production from renewable resources. Enzyme Microb. Technol., 26(2-4), 87-107.

Johnson, D. T. \& Taconi, K. A. (2007). The glycerin glut: Options for the value-added conversion of crude glycerol resulting from biodiesel production. Environ. Progress. 26(4), 338-348.

König, H. \& Berkelmann-Löhnertz, B. (2009). Chapter 25: Maintenance of wine-associated microorganisms. In: Biology of Microorganisms on Grapes. in Must and in Wine. Germany: Springer-Verlag Berlin Heidelberg. 451-468.

Lüthi-Peng, Q., Dileme, F. B. \& Puhan, Z. (2002). Effect of glucose on glycerol bioconversion by Lactobacillus reuteri. Appl. Microbiol. Biotechnol., 59(2-3), 289-296.

National Biodiesel Board. EPA Release June-Biodiesel Volume. [Press release web]. (31 July 2012). [Accesed: Nov. 11, 2012]. Available at: <http://www.nbb.org/news/ nbb-press-releases/press-release-display/2012/07/31/ epa-releases-junebiodiesel-volume>

Okano, K., Tanaka, T., Ogino, C., Fukuda, H. \& Kondo, A. (2010). Biotechnological production of enantiomeric pure lactic acid from renewable resources: recent achievements. perspectives. and limits. Appl. Microbiol. Biotechnol., 85(3), 413- 423.

Sauvageot, N., Gouffi, K., Laplace, J. M. \& Auffray, Y. (2000). Glycerol metabolism in Lactobacillus collinoides: 
production of 3-hydroxypropionaldehyde. A precursor of acrolein. Int. J. Food Microbiol., 55(1-3), 167-170.

Serna-Cock, L. \& Rodríguez-de Stouvenel, A. (2005). Producción biotecnológica de ácido láctico: estado del arte. Ciencia y tecnología alimentaria, 5(001), 54 - 56.

Sims. B. Biodiesel: a global perspective. Biodiesel Magazine. [Press release web. 2007]. < http://www.biodieselmagazine.com/article.jsp?article id=1961>

Wee, Y. J., Kim, J. N. \& Ryu, H. W. (2006). Biotechnological production of Lactid Acid and its recent applications. Food Technol. Biotechnol., 44(2), 163-172.

Yazdani, S. S. \& Gonzalez, R. (2007). Anaerobic fermentation of glycerol: a path to economic viability for the biofuels industry. Current Opin. Biotechnol., 18(3), 213- 219.

\section{AUTHORS}

\section{Yessica Prada-Palomo.}

Affiliation: Universidad Industrial de Santander. Química, Universidad Industrial de Santander. e-mail: prada.jessica@gmail.com

\section{Marly Romero-Vanegas.}

Affiliation: Universidad Industrial de Santander.

Bacteriología y Laboratorio Clínico, Universidad Industrial de Santander.

e-mail: karolinaromero89@hotmail.com

\section{Pedro Díaz-Ruíz.}

Affiliation: Universidad Industrial de Santander. Química, Universidad Industrial de Santander. e-mail: pedro.diaz.ruiz@hotmail.com

\section{Daniel Molina-Velasco.}

Affiliation: Universidad Industrial de Santander. Química, Esp. Docencia Universitaria, M. Sc. Química, $\mathrm{Ph}$. D. Química, Universidad Industrial de Santander. e-mail:dmolina@uis.edu.co

\section{Carolina Guzmán-Luna.}

Affiliation: Universidad Industrial de Santander. Bacteriología y Laboratorio Clínico, Universidad Industrial de Santander. e-mail: cgluna74@gmail.com 
